\title{
Additional Pertalite Policy and Gasoline Consumption Patterns in Indonesia
}

\author{
Nur Laila Widyastuti ${ }^{1}$ \\ Ministry of National Development Planning/BAPPENAS
}

\begin{abstract}
Transport sector is the largest contributor of $\mathrm{CO} 2$ emissions in Indonesia. To reduce the emissions, a policy of adding pertalite is applied which aims to allow consumers to switch into higher quality gasoline. This paper examines the impact of the implementation of the policy of adding pertalite. The approach uses fixed effect of panel data estimation method. In the period 2010-2015 Pertamax prices have a negative impact on Pertamax and Premium consumption. Meanwhile, the prices and revenues of selling Premium have a positive impact on consumption of Pertamax and Premium. For the period of 2016, the impact of the Pertamax prices increase would be a decrease in Pertamax and Premium consumption. Changes in the pattern of gasoline consumption is possible because of the difference in price and supply constraints for each type of gasoline. Therefore, the government should control the supply of gasolines and the differences in gasoline prices so that more Premium consumers will switch to Pertalite, and Pertalite consumers will switch to Pertamax.
\end{abstract}

Keywords: Pertamax, Pertalite, Premium, Price, Consumption 


\section{Kebijakan Penambahan Pertalite dan Pola Konsumsi Bensin di Indonesia}

Nur Laila Widyastuti, BAPPENAS

\section{Pendahuluan}

Indonesia merupakan salah satu negara yang diandalkan dalam penurunan emisi Gas Rumah Kaca (GRK) di dunia. Hal tersebut tidak terlepas dari keikutsertaan Indonesia dalam penandatanganan komitmen penurunan emisi GRK dalam pertemuan G-20 di Pitssburg dan COP-15 oleh UNFCCC. Jumlah emisi GRK yang akan diturunkan adalah sebesar $26 \%$ atau sebesar $41 \%$ dengan dukungan internasional. Selain itu, komitmen tersebut juga telah dituangkan pada Rencana Pembangunan Jangka Menengah (RPJMN) 2015 - 2019 dan Rencana Kerja Pemerintah (RKP) pada setiap tahunnya. Dalam RPJMN maupun RKP, Kebijakan pemerintah dalam usaha penurunan Emisi GRK telah dituangkan dalam tahapantahapan yang jelas.

Namun sampai saat ini pengurangan emisi GRK di Indonesia masih belum mendapatkan hasil yang cukup signifikan. Hal ini ditandai dengan masih tingginya emisi GRK yakni sebesar $814.71 \mathrm{MtCO} 2 \mathrm{e}$ atau $1.9 \%$ dari dunia seperti yang dilaporkan oleh World Research Institute (WRI) tahun 2014. Jumlah emisi tersebut berasal dari berbagai sektor perekonomian yakni kehutanan dan lahan gambut, pertanian, energi dan transportasi, industri, dan limbah. Sektor transportasi berdasarkan proyeksi Business As Usual (BAU) akan meningkat dua kali lipat dari tahun 2010 sebesar 5 juta ton CO2 menjadi 10 juta ton CO2 pada tahun 2020. Target pengurangan emisi GRK pada sektor transportasi diharapkan sebesar 0,036\% pada tahun 2019.

Berbagai kebijakan untuk pengurangan Emisi GRK di sektor transportasi terutama transportasi darat telah banyak dilakukan oleh pemerintah. Salah satu kebijakan yang dilakukan pemerintah adalah melakukan fuel switching yakni dari Bahan Bakar Minyak (BBM) ke Bahan Bakar Gas (BBG) maupun Bahan Bakar Nabati (BBN). Berdasarkan evaluasi yang dilakukan oleh Kementerian ESDM tahun 2015, penerapan fuel switching mengalami beberapa kendala yang membutuhkan penyelesaian jangka panjang. Kendala yang dihadapi dalam penerapan BBG pada sektor transportasi antara lain: 1) pembangunan infrastruktur pengisian BBG seperti depo BBG dan SPBG banyak terkendala pada pembebasan tanah, ijin, pasokan listrik dan masyarakat sekitar; 2) Konverter Kit untuk BBG masih relatif mahal dan belum dapat diterapkan pada semua kendaraan; 3) Perbedaan harga yang tidak terlalu jauh dengan bensin reguler. Sedangkan untuk penggunaan BBN pada sektor transportasi mengalami kendala antara lain: 1) Masih sedikitnya infrastruktur BBN; 2) Masih tingginya biaya pengolahan BBN dibandingkan dengan harga jual sehingga memerlukan subsidi harga; 3) Masih terbatasnya konverter kit untuk BBN dan relatif mahal. Sampai saat ini, kedua alternatif Bahan bakar tersebut hanya cukup efektif dijalankan pada transportasi umum yang ada di DKI Jakarta dibuktikan dengan banyaknya SPBG yang dibangun di daerah Jabodetabek berdasarkan laporan KESDM tahun 2015. Kendala-kendala tersebut yang menghambat kebijakan Fuel Swtching Bahan bakar untuk mengurangi emisi GRK dalam jangka pendek. Pemerintah harus mulai mencari alternatif kebijakan lainnya untuk mengurangi emisi GRK dalam jangka pendek.

Alternatif kebijakan yang dapat diadopsi untuk pengurangan emisi GRK di sektor transportasi dalam jangka pendek adalah kebijakan pemerintah Amerika dan Europe Union (EU) dalam mandat penggunaan bensin oktan tinggi untuk mobil pribadi seperti yang dilaporkan oleh United States Environmental Protection Agency (EPA) dan Europe Environmental Agency (EEA) tahun 2016. Kebijakan tersebut akan dilaksanakan mulai tahun 2016 dengan menaikkan standard bensin dari semula oktan 87 menjadi oktan 95. Dengan diberlakukannya kebijakan tersebut, Pemerintah Amerika berharap akan adanya pengurangan emisi GRK sebanyak 6 Miliar Metric Ton pada akhir tahun 2025. Sedangkan EU telah menerapkan penggunaan oktan 95 semenjak tahun 2004 berdasarkan laporan dari European Comission Tahun 2015. 
Menurut laporan Europe Enviromental Agency bahwa EU telah berhasil menurunkan emisi GRK sebesar 8,2\% dari tahun 2008 sampai 2013. Selain pengurangan emisi GRK, penggunaan bensin oktan tinggi juga mempunyai keuntungan dalam efisiensi. Pemerintah Amerika telah melakukan perhitungan, apabila kebijakan kenaikan standar oktan 95 telah dilakukan maka pemerintah Amerika Serikat dapat menghemat biaya bahan bakar sebanyak US\$ 1.7 Triliun dan mengurangi ketergantungan pada minyak sebanyak 2 juta barel perhari pada tahun 2025.

Dalam penelitian yang dilakukan oleh Speth (2014), dilaporkan bahwa penggunaan oktan tinggi akan dapat menurunkan konsumsi bensin United States (US) sebanyak $3-4.4 \%$. selain itu, pemakaian bensin oktan tinggi akan menurunkan emisi di US sebanyak 19-35 Juta ton/tahun pada tahun 2040. Keuntungan tahunan secara ekonomi juga meningkat sebanyak \$0.4-6.4 miliar pada tahun 2040, dan keuntungan sosial tahunan dari biaya karbon sebanyak \$1.7-8.8 miliar di 2040.

Penggunaan bensin Oktan 90 keatas yakni Pertamax masih belum populer di masyarakat Indonesia. PT Pertamina sebagai produsen dan distributor terbesar pasar bensin memproduksi dan mendistribusikan bensin dengan oktan 88 yakni "Premium". Jenis BBM ini mendominasi pasar bensin di Indonesia walaupun subsidi untuk premium telah dicabut. Selain melakukan pencabutan subsidi premium, pemerintah Indonesia melalui PT. Pertamina juga menambah berbagai varian baru jenis produk oktan tinggi yakni pertalite yang mempunyai oktan 90 mulai tahun 2015. Penambahan varian tersebut dilakukan pemerintah untuk melakukan slow migration pada pola konsumsi bahan bakar minyak di Indonesia agar mencapai fuel economy seperti yang telah diinsiasi oleh negara-negara lain.

Gambar 1. Konsumsi Pertamax dan Premium tahun 2000-2015

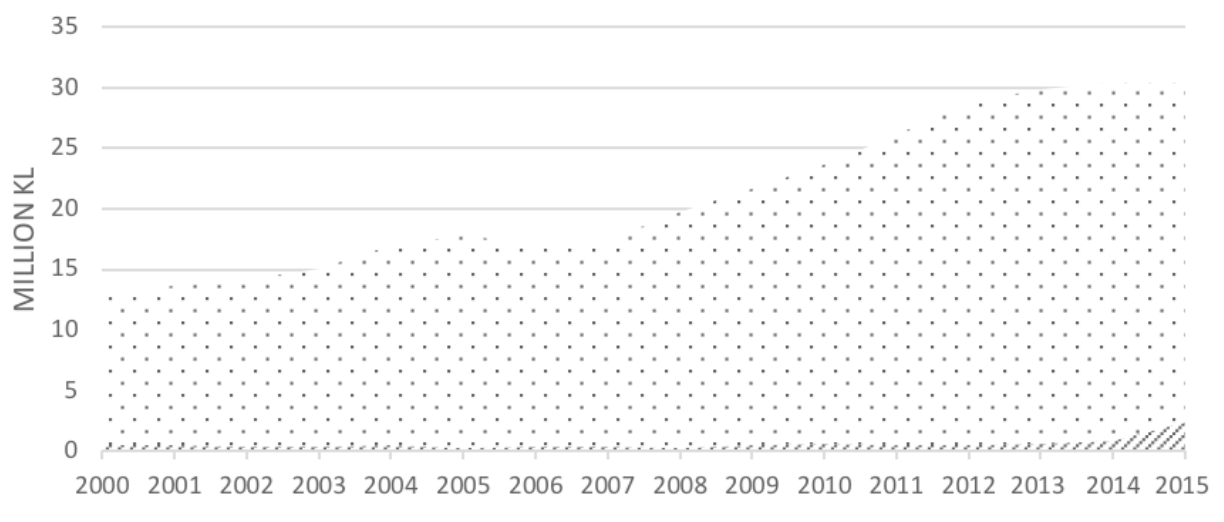

ๆ PERTAMAX - PREMIUM

\section{Sumber: Pertamina}

Seiring dengan adanya penambahan varian baru pada jenis bensin, maka preferensi dari konsumen akan mengalami pergeseran dan lebih sensitif terhadap adanya selisih harga yang akan menimbulkan fenomena pergeseran pola konsumsi masyarakat. Respon kualitas yang terdapat pada fenomena tersebut diharapkan terjadi di pasar bensin Indonesia. Pemerintah dapat melakukan pengendalian terhadap harga relatif di antara jenis bensin sehingga pilihan konsumen tidak bergeser dari barang berkualitas tinggi ke rendah. Selain itu, konsumen juga didorong untuk berganti ke bensin yang mempunyai kualitas lebih tinggi. Pada gambar 1.2 dapat dilihat bahwa harga Pertamax (bensin berkualitas tinggi) di Indonesia sangat mengikuti harga minyak mentah sehingga sangat rentan akan kenaikan harga yang sangat tinggi. Penelitian yang dilakukan oleh Hastings \& Shapiro (2013)menyatakan bahwa pangsa pasar bensin kualitas tinggi mudah untuk kehilangan konsumen ketika terjadi kenaikan harga bensin; fenomena tersebut disebut dengan buying down. Penelitian ini penting untuk mengetahui dampak dari kebijakan penambahan varian baru. Hal ini dilakukan agar tidak terjadi pergeseran preferensi konsumen dari barang berkualitas tinggi ke barang berkualitas lebih rendah sehingga dapat memicu kelangkaan jenis bensin kualitas tertentu. 
Gambar 2. Pola harga Pertamax terhadap harga minyak mentah 2010-2014

\section{Pertamax dan Harga Minyak Mentah 2010 - 2014}

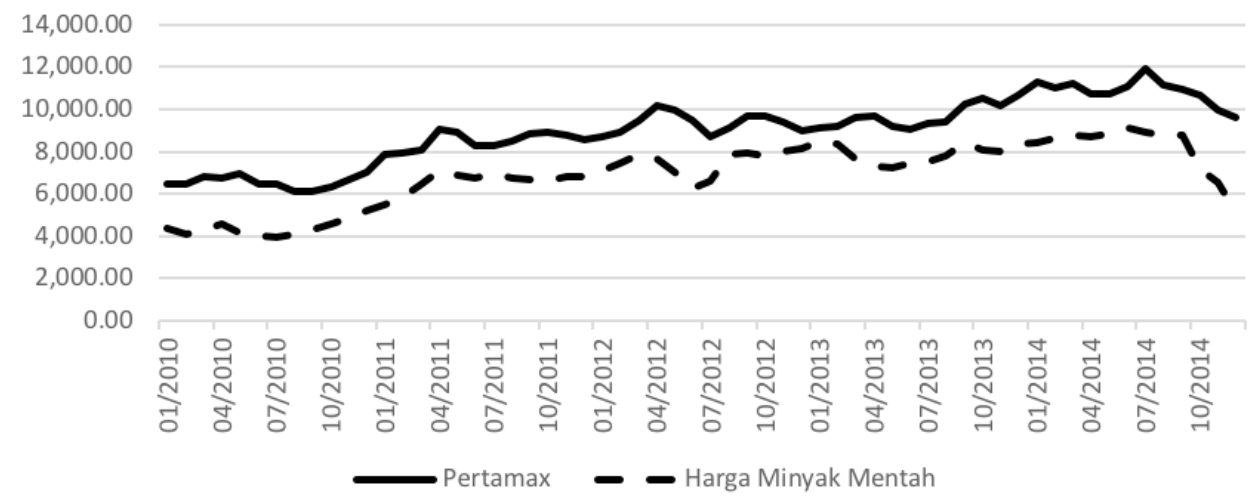

Sumber: BPS, diolah

Dari uraian di atas dapat dirumuskan bahwa permasalahan yang akan diangkat oleh makalah ini adalah1) Bagaimanakah pola konsumsi bensin sebelum adanya kebijakan penambahan Pertalite dan 2) Bagaimanakah pola konsumsi bensin setelah adanya kebijakan penambahan Pertalite. Dengan mengidentifikasi pola konsumsi sebelum dan sesudah adanya kebijakan penambahan Pertalite, maka akan dapat dilihat apakah dampak dari kebijakan tersebut efektif untuk memaksa konsumen bensin melakukan slow migration ke dari oktan rendah ke oktan yang lebih tinggi. Makalah ini terdiri dari pendahuluan, kerangka teori dan konseptual, metodologi, hasil, dan kesimpulan.

\section{Tinjauan Pustaka}

Kerangka konseptual yang digunakan dalam studi ini mengacu pada kerangka konseptual yang telah dibentuk oleh Howard et.al (1993), Dahl (1994), Siddiqui (2000), Baruna (2009), and Lin and Prince (2013). Konsumsi BBM adalah fungsi dari pendapatan, harga relatif, gaya hidup dan struktur ekonomi. Selain itu, konsumsi BBM juga memiliki hubungan positif dengan pendapatan dan berhubungan negatif dengan harganya sendiri. Diasumsikan setiap individu akan memaksimalkan fungsi utilitasnya terhadap kendala biaya dimana utilitas yang dikonsumsi hanya 2 komoditi yakni komoditi bbm $\left(\mathrm{q}_{1}\right)$ dan komoditi lainnya $\left(\mathrm{q}_{2}\right)$, maka fungsi utilitasnya dapat dituliskan menjadi:

$$
U=f\left(q_{1}, q_{2}\right)
$$

Dengan kendala anggaran yang dihadapi konsumen:

$$
Y=p_{1} q_{1}+p_{2} q_{2}
$$

Dimana $Y$ adalah pendapatan konsumen yang diasumsikan tetap dan p1, p2 adalah harga barang 1 dan 2. Selanjutnya persamaan (2.1) lebih dapat dispesifikkan. Mmenurut Narayan and Smith (2007), bahwa setiap konsumsi komoditi $\mathrm{q}_{1}$ dipengaruhi oleh GDP, harga dari BBM $\left(P_{i}\right)$ dan harga dari komoditi lainnya $(P x)$ tersebut:

$$
q_{1}=\left(b b m_{i}\left(P_{i}\right), P x, G D P \ldots\right)
$$

Dimana bbm adalah pilihan jenin bensin yang akan dipilih dan $\mathrm{P}_{\mathrm{i}}, \mathrm{P}_{\mathrm{x}^{\prime}}$ GDP.... $\geq 0$. Dari persamaan (2.2) dapat disubstitusikan ke (2.1) menjadi:

$$
U=u\left(b b m_{i}(P i, P x, G D P), q_{2}(P i, P x, G D P,)\right)
$$


Persamaan (2.3) dapat diartikan bahwa fungsi utilitas dari konsumsi bensin dipengaruhi oleh jumlah realisasi bensin dikalikan dengan harga dan juga oleh pertumbuhan ekonomi. Guna memudahkan, maka diasumsikan bahwa $\mathrm{bbm}_{1}$ adalah komoditi premium dan $\mathrm{bbm}_{2}$ adalah komoditi bensin oktan $\geq 90$. Untuk kasus di Indonesia, jumlah dari bbm ${ }_{1}$ akan selalu lebih besar dibandingkan dengan bbm. Sedangkan untuk $\mathrm{P}_{1}$ atau harga premium akan selalu lebih rendah dibandingkan dengan $P_{2}$ atau harga bensin oktan $\geq 90$. Maka persamaan (2.3) dapat dituliskan kembali menjadi:

$$
U=u\left(b b m_{i}(P i, P x, G D P), q_{2}(P i, P x, G D P)\right)
$$

Untuk dapat memutuskan berapa banyak konsumsi optimum untuk semua jenis bensin, maka individu akan memperhitungkan anggaran yang dimiliki sebesar:

$$
Y=P_{i} b b m_{i}+P_{x} q_{2}
$$

Persamaan (2.4) dan (2.5) dapat dituliskan kembali menjadi fungsi langrange dengan memasukkan unsur waktu t sebagai berikut:

$$
\mathcal{L}=u\left(b b m_{i t}\left(P_{i t}, P_{x t}, G D P_{t}\right), q_{2 t}\left(P_{i t}, P_{x t}, G D P_{t}\right)\right)+\lambda P_{i t} b b m_{i t}+P_{x t} q_{2 t}
$$

Dengan demikian, optimasi dari fungsi utilitas dan kendala di atas akan menghasilkan fungsi permintaan optimum untuk jenis bensin premium, jenis bbm oktan $\geq 90$ dan non-bbm sebagai berikut:

$$
\begin{aligned}
& D_{b b m_{1 t}}=f^{1}\left(P_{1 t}, P_{x t}, m\right) \\
& D_{b b m_{2 t}}=f^{1}\left(P_{2 t}, P_{x t}, m\right)
\end{aligned}
$$

Diasumsikan bahwa individu lebih banyak yang mengkonsumsi bbm dibandingkan dengan bbm $_{2}$ dikarenakan harganya yang lebih rendah dan individu juga lebih memperhatikan harga $P_{i}$ dibandingkan dengan $P_{x}$. Untuk mengetahui pengaruh perubahan $P_{1 t}$ relatif terhadap $P_{2 t}$ yang menyebabkan perubahan pola konsumsi, menurut Shiddiqui dalam Baruna (2009) dan Lin dan Prince (2013), dapat dilakukan perhitungan elastisitas dengan cara sebagai berikut:

$$
\frac{\vartheta \ln D b b m_{i t}}{\vartheta \ln P_{i t}}=\beta_{i t}
$$

Dimana $\beta_{i}$ adalah elastisitas permintaan bbm akibat dari perubahan harga. Sedangkan untuk menghitung elastisitas permintaan bbm akibat dari perubahan pendapatan dapat dilakukan perhitungan sebagai berikut:

$$
\frac{\vartheta \ln D b b m_{i t}}{\vartheta \ln G D P R i t}=\beta r_{i t}
$$

Dimana $\beta r_{i t}$ adalah elastisitas permintaan bbm akibat dari perubahan pendapatan. Sedangkan untuk menghitung elastisitas silang dari dua barang subtitusi, dilakukan perhitungan sebagai berikut:

$$
\frac{\vartheta \ln D b b m_{1 t}}{\vartheta \ln P_{2 t}}=\beta s_{i t}
$$

Dimana $\beta r_{i t}$ adalah elastisitas silang permintaan bensin premium terhadap harga dari bensin oktan 90 keatas.

Beberapa penelitian yang terkait dengan analisa konsumsi bensin dan pendapatan juga telah banyak dilakukan. Berbagai metode dan variabel digunakan untuk melakukan analisis 
sebagai berikut: metode time series dan data time series (Al Faris, 1993); data panel dengan variabel bebas harga, pendapatan dan jumlah kendaraan (Eltony, 1994); data time series dan metode Error Correction Model (Ramanathan, 1999); data time series dan metode ECM serta Partial Adjustment Model (PAM) (Dahl dan Kurtubi, 2001); Data time series dan metode OLS (Siddiqui, 2003), ditambahkan variabel harga alkohol dan metode ECM (Alves et al, 2003); data cross section (Sophiana 2006); data kwartal dengan metode kointegrasi dan ECM (Brons, 2008); data cross section dan ditambahkan variabel jumlah kendaraan (Butar-butar, 2008); data panel (Baruna, 2009); data time series dan metode OLS (Lin dan Prince, 2013). Semua penelitian sebelumnya ini menggunakan variabel dependen yakni permintaan atau konsumsi bbm sedangkan variabel independennya berupa pendapatan dan harga masing-masing bbm.

Umumnya penelitian-penelitian sebelumnya lebih cenderung menganalisa konsumsi bensin premium dan solar yang banyak digunakan oleh masyarakat seperti penelitian yang dilakukan oleh Baruna tahun 2009. Dalam penelitian tersebut dilakukan analisis Fixed effect untuk jenis BBM seperti Premium, Solar, Minyak Tanah dan LPG. Data yang digunakan merupakan data sekunder dengan jenis data yakni data panel. Baruna (2009) mengidentifikasi pengaruh harga yang memberikan kontribusi yang signifikan bagi konsumsi premium, solar dan minyak tanah. Selain itu dalam penelitian tersebut juga diidentifikasi pengaruh pendapatan terhadap konsumsi premium solar dan minyak tanah. Penelitian Baruna (2009) akan menjadi landasan dan acuan untuk pengembangan model dan analisis dalam penelitian ini.

\section{Metodologi}

Data yang digunakan dalam penelitian ini berupa data sekunder data panel. Data diperoleh dari beberapa sumber antara lain Pusat Data dan Informasi Kementerian Energi dan Sumber Daya Mineral (KESDM), Direktorat Pembinaan Usaha Hilir Kementerian ESDM, Badan Pengusahaan Hilir Migas KESDM, Badan Pusat Statistik, dan PT. Pertamina. Data yang digunakan antara lain (1) Data penjualan varian bensin Premium, Pertalite dan Pertamax Perbulan Per provinsi dari tahun 2009- 2016; (2) Data harga nominal Premium, Pertalite dan Pertamax Perbulan Perprovinsi dari tahun 2009-20016; dan (3) Data PDRB triwulanan.

Data yang digunakan terdiri dari 34 provinsi yang ada di Indonesia. Sedangkan untuk jangka waktu (time series) dibedakan menjadi dua yakni 1) data sebelum adanya Pertalite akan menggunakan data bulanan dari Januari 2010 (2010m1) sampai Desember 2015 (2015m12) dan 2) data setelah adanya pertalite yakni dari Januari 2016 (2016m1) sampai Desember 2016 (2016m12). Maka jumlah observasi untuk data sebelum adanya Pertalite sebanyak 2040 observasi dan data setelah adanya observasi sebanyak 408 observasi. Maka dapat disimpulkan bahwa teknik pengolahan data menggunakan regresi panel data karena data yang diolah adalah observasi bersifat pooling cross section dan diteliti sejalan dengan perubahan waktu.

Model empiris yang digunakan dalalm penelitian ini mengacu pada Dahl (1994). Model yang akan digunakan untuk melakukan regresi terhadap fungsi permintaan adalah sebagai berikut:

$$
\begin{aligned}
& D_{b b m^{\text {Prem }}}=f\left(P^{\text {prem }} t, P^{\text {pmax }} t, P^{\text {lite }} t, P D B_{t . . .}\right. \\
& D_{b b m^{\text {Pmax }}}=f\left(P^{\text {pmax }} t, P^{\text {prem }} t, P^{\text {lite }} t, P D B_{t \risingdotseq}\right) \\
& D_{b b m^{\text {Plite }}}=f\left(P^{\text {lite }} t, P^{\text {pmax }} t, P^{\text {prem }} t P D B_{t !}\right)
\end{aligned}
$$
berikut:

Dari persamaan (3.1), (3.2) dan (3.3) dapat dibentuk suatu fungsi logaritma sebagai

$$
\begin{aligned}
& \begin{aligned}
\operatorname{LogDbbm}_{i t}^{\text {Prem }} & \\
& =\alpha_{1}+\beta_{1} \log P^{\text {prem }}
\end{aligned} \\
& +\beta_{2} \log P^{\text {pmax }} i t+\beta_{3} \log P^{\text {lite }} i t+\beta_{4} \log P D B_{i t \text {. }} \\
& \operatorname{LogDbbm}_{i t}^{\text {Pmax }} \\
& =\alpha_{2}+\beta_{5} \log P^{p r e m} i t+\beta_{6} \log P^{p m a x} i t+\beta_{7} \log P^{\text {lite }} i t+\beta_{8} \log P D B_{i t \text { ] }} \\
& \operatorname{LogDbbm}_{\text {it }}^{\text {Plite }}=\alpha_{3}+\beta_{9} \log _{\text {Prem }} \text { it } \\
& +\beta_{10} \log P^{\text {max }} i t+\beta_{11} \log P^{\text {lite }} i t+\beta_{12} \log P D B_{i t}
\end{aligned}
$$


Dimana:

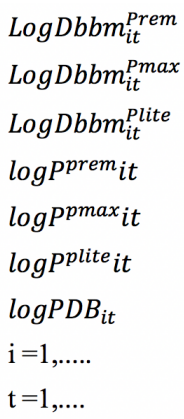

= Logaritma dari konsumsi premium dari tahun 2000-2016

= Logaritma dari konsumsi pertamax dari tahun 2000-2016

= Logaritma dari konsumsi pertalite tahun 2016

= Logaritma harga premium dari tahun 2000-2016

= Logaritma harga pertamax dari tahun 2000-2016

= Logaritma harga pertalite tahun 2016

= Logaritma pendapatan nasional tahun 2000-2016

= banyaknya wilayah

= banyaknya waktu

Pemilihan penggunaan metode analisis data panel dikarenakan data yang digunakan mempunyai unsur cross section berupa wilayah dan time series berupa tahun (Ekananda, 2015). Untuk mendapat analisis data panel yang baik maka perlu dilakukan 3 tahapan uji, yakni:

a. Uji Breusch Pagan untuk memilih apakah model yang akan digunakan merupakan model tanpa efek individu (common effect) atau model dengan efek individu (individual effect)

b. Apabila diperoleh model dengan efek individu maka dilanjutkan dengan uji hausman. Uji ini akan digunakan untuk melihat apakah efek individu tersebut mempunyai jenis efek tetap (fixed effect) atau efek acak (random effect).

c. Jika setelah dilakukan uji Hausman dan diperoleh hasil bahwa model tersebut adalah model efek tetap (fixed effect) maka dilanjutkan dengan uji LM. Uji ini digunakan untuk mengetahui struktur data bersifat homoskedastik atau heteroskedastik.

\section{Pembahasan Masalah}

Dari tabel-1 dapat diketahui bahwa setiap adanya perubahan harga jenis bensin mempengaruhi konsumsi Pertamax. Ketika terjadi kenaikan dari harga Pertamax sebesar $1 \%$ maka akan terjadi penurunan konsumsi Pertamax sebesar $0.174 \%$. Sedangkan jika terjadi kenaikan harga Premium sebesar $1 \%$ maka akan terjadi kenaikan konsumsi Premium sebesar $2.1 \%$. Begitu juga ketika terjadi kenaikan pendapatan sebesar $1 \%$ maka akan terjadi kenaikan konsumsi Pertamax sebesar 1.3\%. Konsumsi Pertamax paling besar dipengaruhi oleh harga dari Premium sehingga bisa disimpulkan bahwa Premium merupakan barang substitusi untuk Pertamax. Kemungkinan kecenderungan konsumen untuk mengganti pilihan bensin dari Premium ke Pertamax dikarenakan selisih harga dari keduanya yang semakin kecil sehingga membuat konsumen beralih ke Pertamax. Sehingga pada periode tahun 2010-2015, konsumen akan beralih dari Premium ke Pertamax ketika terjadi kenaikan harga Premium maupun Pertamax.Selain itu, pendapatan konsumen juga signifikan mempengaruhi tingkat konsumsi Pertamax. Semakin tinggi kenaikan pendapatan yang diperoleh oleh konsumen, maka akan lebih tinggi pula keinginan konsumen untuk berganti ke Pertamax. 
Tabel 1. Hasil regresi konsumsi Pertamax tahun 2010-2015

\begin{tabular}{|c|c|}
\hline & QPertamax \\
\hline \multirow[t]{2}{*}{ PPertamax } & $-0.174 * *$ \\
\hline & {$[0.0731]$} \\
\hline \multirow[t]{2}{*}{ PPremium } & $2.107 * * * *$ \\
\hline & {$[0.207]$} \\
\hline \multirow[t]{2}{*}{ Income } & $1.327 * \star \star \star *$ \\
\hline & {$[0.0297]$} \\
\hline \multirow[t]{2}{*}{ _cons } & 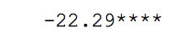 \\
\hline & [1.983] \\
\hline $\mathrm{N}$ & 2016 \\
\hline
\end{tabular}

Dalam tabel-2 diketahui bahwa harga pertamax tidak signifikan secara statistik untuk digunakan melakukan estimasi pada konsumsi pertamax. Hubungan signifikan terlihat pada hubungan antara harga dan jumlah konsumsi premium. Ketika terjadi kenaikan harga Premium sebesar $0.75 \%$ maka akan terjadi kenaikan konsumsi Premium sebesar $0.7 \%$. Sedangkan jika terjadi kenaikan pendapatan sebesar $1 \%$ maka akan terjadi kenaikan konsumsi Premium sebasar $0.6 \%$. Dari hasil regresi tersebut dapat terlihat bahwa pola konsumsi Premium di Indonesia dipengaruhi oleh harga Premium dan Pendapatan . Hal ini dimungkinkan karena konsumen tidak terlalu peduli dengan naik turunnya harga Premium dikarenakan Premium sudah bergeser menjadi barang kebutuhan pokok untuk dapat melakukan aktivitas ekonomi. Sedangkan untuk kenaikan konsumsi dikarenakan naiknya pendapatan dimungkinkan karena: 1) konsumen membutuhkan konsumsi premium untuk dapat melakukan aktivitas tambahan yang dapat menaikkan pendapatan; dan 2) Konsumen cenderung untuk mengkonsumsi Premium lebih banyak ketika pendapatan meningkat seperti traveling dan membeli kendaraan baru.

Tabel 2. Hasil regresi konsumsi Premium tahun 2010-2015

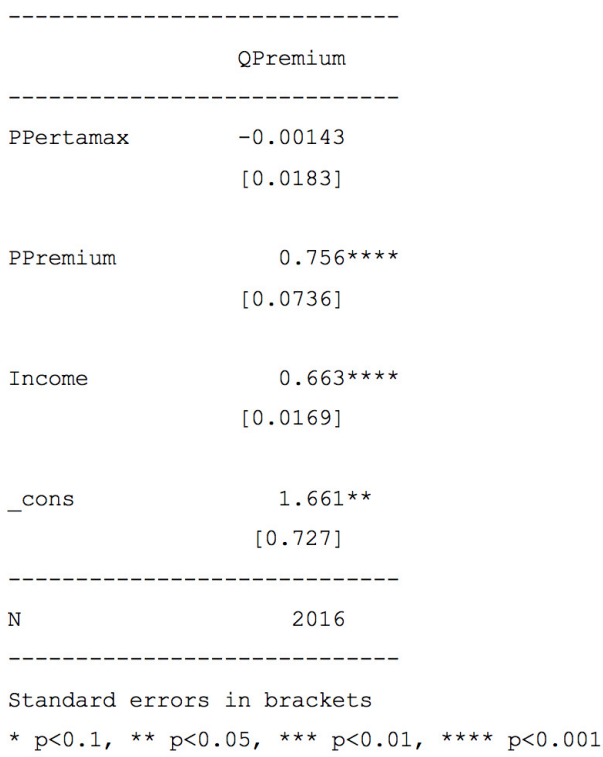


Pada tabel-3 terlihat pada hasil regresi Pertamax tahun 2016 bahwa ketika terjadi kenaikan harga Pertamax sebesar 1\% maka akan terjadi penurunan konsumsi Pertamax sebesar $7.4 \%$. Penurunan konsumsi Pertamax dikarenakan adanya kenaikan harga mengindikasikan bahwa konsumen cenderung untuk berpindah ke Pertalite atau Premium ketika terjadi kenaikan harga Pertamax. Harga Pertamax mempunyai dampak yang besar terhadap besar kecilnya konsumsi Pertamax pada masyarakat. Selain itu, ketika ada kenaikan harga Pertalite sebesar $1 \%$ maka akan terjadi kenaikan konsumsi Pertamax sebesar $0.73 \%$. Hal ini mengindikasikan bahwa konsumen Pertalite akan melakukan perpindahan ke Pertamax apabila harga Pertalite mengalami kenaikan. Perpindahan ini dimungkinkan karena selisih harga antara Pertamax dan Pertalite akan semakin kecil sehingga konsumen akan lebih memilih bensin dengan jenis kualitas yang lebih bagus dan dapat memaksimalkan utilitas konsumen. Hasil regresi pada tabel 4.3 juga menjelaskan bahwa ketika terjadi kenaikan harga Premium sebesar $1 \%$ maka akan terjadi kenaikan konsumsi Pertamax sebesar $19.2 \%$. Hal ini juga memperlihatkan bahwa konsumen akan berpindah ke Pertamax ketika terjadi kenaikan harga Premium dikarenakan selisih harga antara Premium dan Pertamax semakin kecil sehingga mendorong konsumen untuk memilih Pertamax yang mempunyai kualitas lebih baik. Jika terjadi kenaikan pendapatan sebesar $1 \%$ maka akan terjadi kenaikan konsumsi Pertamax sebesar $0.089 \%$.

Tabel 3. Hasil regresi Pertamax tahun 2016

\begin{tabular}{|c|c|}
\hline & QPertamax \\
\hline PPertamax & $\begin{array}{l}-7.452^{\star \star \star \star} \\
{[0.577]}\end{array}$ \\
\hline PPertalite & $\begin{array}{l}0.731 * \star \star \star \\
{[0.0349]}\end{array}$ \\
\hline PPremium & $\begin{array}{l}19.23 * \star \star \star \\
{[3.125]}\end{array}$ \\
\hline Income & $\begin{array}{l}0.0887 * * \\
{[0.0445]}\end{array}$ \\
\hline _cons & $\begin{array}{l}-94.49 * * * * \\
{[27.07]}\end{array}$ \\
\hline $\mathrm{N}$ & 317 \\
\hline
\end{tabular}

Pada tabel-4 terlihat bahwa harga Pertamax dan Premium tidak signifikan secara statistik untuk menjelaskan perubahan konsumsi Pertalite. Hal ini dimungkinkan dampak harga Pertamax dan Premium mempunyai rentang jangka panjang, sedangkan data yang digunakan terbatas untuk kurun waktu 1 tahun sehingga dampak jangka panjang tidak tertangkap. Hasil signifikan terdapat pada kenaikan harga Pertalite sebesar $1 \%$ yang meningkatkan kenaikan konsumsi Pertalite sebesar $1 \%$. Hasil regresi tersebut mengindikasikan bahwa beberapa konsumen tetap melakukan konsumsi di Pertalite tanpa memperdulikan kenaikan harga pertalite dikarenakan 1) Suplai Premium yang semakin sesikit di beberapa daerah terutama Jabodetabek membuat konsumen harus mengkonsumsi Pertalite; 2) Harga Pertalite yang berselisih kecil dengan premium membuat konsumen enggan untuk kembali ke Premium walaupun ada kenaikan harga Pertalite. 
Tabel 4. Hasil regresi Pertalite tahun 2016

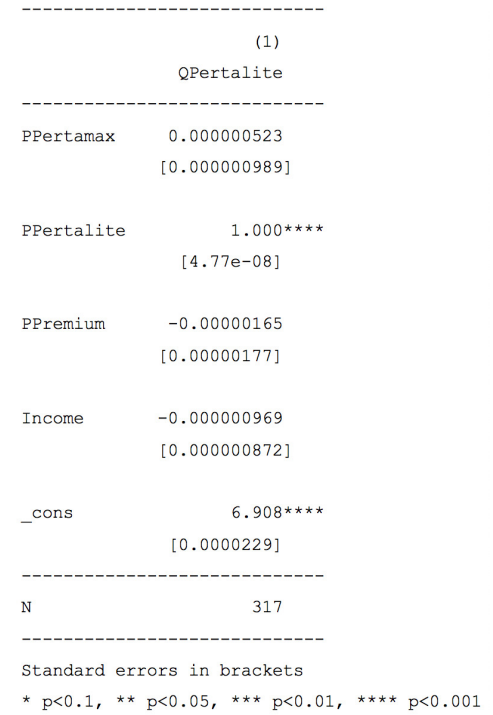

Pada tabel-5 mengenai hasil regresi premium tahun 2016 terlihat bahwa perubahan harga dari ketiga jenis varian bensin sangat mempengaruhi konsumsi Premium. Jika terjadi kenaikan harga Pertamax sebesar $1 \%$ maka akan terjadi penurunan Premium sebesar $1.4 \%$. Hal ini mengindikasikan bahwa konsumen akan memilih untuk bergeser ke Pertalite dibandingkan ke Premium dikarenakan selisih harga antara Pertamax dan Pertalite akan semakin lebar. Pilihan konsumen Pertamax untuk tidak berpindah ke Premium dimungkinkan untuk mendapatkan kualitas bensin yang tetap baik namun masih terjangkau. Selain itu, hasil analisis regresi lainnya menyatakan bahwa kenaikan Pertalite sebesar $0.36 \%$ maka akan mengakibatkan kenaikan konsumsi Premium sebesar $0.36 \%$. Hal ini memperlihatkan bahwa konsumen Pertalite akan mengubah preferensi ke Premium ketika terjadi kenaikan harga dari Pertalite. Apabila ada kenaikan harga premium sebesar $1 \%$ maka akan terjadi kenaikan Premium sebesar $11.56 \%$. Hasil regresi ini memperlihatkan bahwa Premium masih menjadi pilihan utama masyarakat walaupun mengalami kenaikan harga. Tingginya nilai prosentase perubahan tersebut dimungkinkan pula merupakan limpahan konsumen dari jenis bensin kualitas tinggi dan menengah karena kenaikan harga premium kemungkinan besar seiring dengan kenaikan harga jenis bensin lainnya.

Tabel 5. Hasil regresi Premium tahun 2016

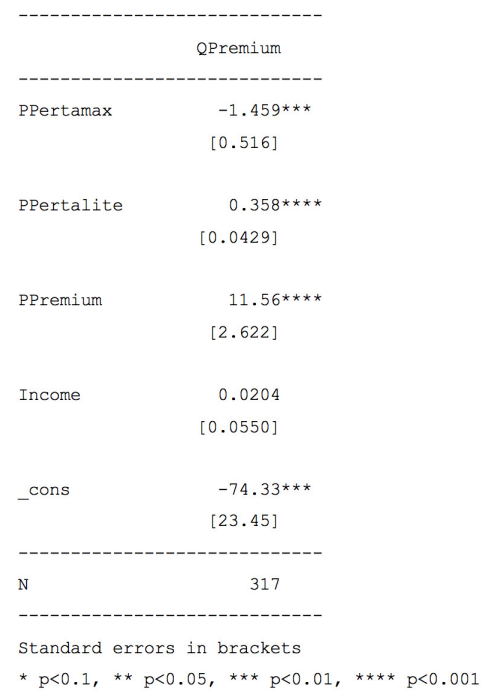




\section{Kesimpulan dan Rekomendasi Kebijakan}

Dari hasil analisis ditemukan bahwa pada periode tahun 2010-2015, harga Pertamax berdampak negatif pada konsumsi Pertamax maupun Premium. Namun, untuk harga Premium dan pendapatan berdampak positif terhadap konsumsi Pertamax maupun Premium. Perubahan konsumen Pertamax ke Premium ketika terjadi kenaikan harga Pertamax membuat selisih harga antara Premium dan Pertamax menjadi lebar sehingga membuat konsumen memindahkan preferensinya ke Pertamax. Pada periode tahun 2016, dampak dari kenaikan harga Pertamax sama dengan periode tahun sebelumnya. Ketika terjadi kenaikan harga Pertamax maka akan terjadi penurunan pada konsumsi Pertamax maupun Premium. Penurunan konsumsi Pertamax maupun premium dimungkinkan karena adanya kendala pada suplai dan semakin kecilnya selisih harga di antara jenis bensin. Untuk Pertalite pada tahun 2016, hasil regresi menunjukkan bahwa konsumen Pertalite tetap melakukan konsumsi Pertalite tanpa mempedulikan kenaikan harga pertalite dikarenakan adanya kendala suplai pada Premium maupun Pertamax dan harga pertalite yang berselisih kecil dengan jenis bensin lainnya.

Kebijakan penambahan Pertalite pada varian bensin mendapat dampak positif dari masyarakat terutama konsumen Premium. Hal ini menunjukkan bahwa gagasaan pemerintah untuk menambah Pertalite berhasil membuat konsumen beralih ke bensin kualitas lebih tinggi. Maka dari itu, pemerintah harus melakukan kontrol terhadap suplai dan selisih harga bensin agar semakin banyak konsumen Premium yang berpindah ke Pertalite dan konsumen Pertalite berpindah ke Pertamax.

Diharapkan pada penelitian selanjutnya yang akan menganalisis dampak dari selisih harga terhadap kualitas barang dapat menggunakan data penelitian yang lebih panjang setelah adanya penambahan jenis kualitas bensin. Selain itu, penelitian selanjutnya dapat menganalisis perubahan pola konsumsi bensin sampai pada level provinsi bahwakan kabupaten/kota sehingga perilaku konsumen lebih tergambar dengan detail sesuai dengan karakteristik daerah masing masing. 


\section{Daftar Pustaka}

Al Faris, Abdul-Razzaq. 1993. Income and price elasticities of gasoline demand in the OAPEC Countries. The Journal of Energy and Development. 17, 2.

Baruna, Eka Satra. 2009. Analisis pengaruh harga dan pendapatan terhadap konsumsi premium, solar dan minyak tanah di Indonesia. Pascasarjana Ilmu Ekonomi FEUI. T 192/09

Brons, Martijn. 2008. A meta-analysis of the price elasticity of gasoline demand. A SUR approach. Energy Economics, 30(5). 2105-2122.

Butar-Butar, H.W.V.H. 2008. Estimasi fungsi permintaan BBM premium dan solar pada sektor transportasi darat di Indonesia periode 1983-2004. Pascasarjana Ilmu Ekonomi FEUI. T 472/08

Chow, Eric W. 2011. Exploring the Use of a Higher Octane Gasoline for the U.S. Light-Duty Vehicle Fleet. Boston University: Boston.

Dahl, C., Kurturbi. 2001. Estimating oil product demand in Indonesia using a cointegrating error correction model. OPEC Review: 25, 1-25.

Eltony, M.N. 1994. An econometric study of the demand for gasoline in the gulf cooperation council countries. Journal of Energy Finance and Development:19(2).

Hastings, Justine S. and Jesse M. Sahipro. 2013. Fungibility and consumer choice: Evidence from Commodity Price Shocks.

Henderson, J.M and Quandt, R.E. 1980. Microeconomic Theory: A Mathematical Approach 3rd ed. McGraw Hills. Inc

Hutabarat, Binsar. 2007. Analisis elastisitas pemakaian beragam energi berbasis fosil dalam jangka panjang dan jangka pendek dengan menggunakan metode kointegrasi dan error correction model (ECM). Pascasarjana Ilmu Ekonomi FEUI. T 303/07.

Jehle, Geoffrey A. And Reny, Phillip J. Advanced Microeconomic Theory 3rd ed. Great Britain: Ashford Colour Press Ltd

Mas-Colell, Andreu. 1995. Microeconomics. New York: Oxford University Press, Inc.

Kementerian Energi dan Sumber Daya Mineral. 2016. Laporan Evaluasi Pencapaian Kinerja Sektor ESDM. Jakarta: KESDM

Kementerian PPN/Bappenas. 2015. Lampiran Pidato Presiden tahun 2015. Jakarta: Bappenas

Kementerian PPN/Bappenas. 2014. Rencana Pembangunan Jangka Menengah 2015-2019. Jakarta: Bappenas

Kementerian PPN/Bappenas. 2014. Rencana Kerja Pemerintah tahun 2015. Jakarta: Bappenas

Ramanathan, R. 1999. Short- and long-run elasticities of gasoline demand in india: an empirical analysis using co-integration techniques. Energy Economics, 21(4), 321-220.

Sallee, James. 2015. Do Consumers Recognize the Value of Fuel Economy? Evidence from Used Car Prices and Gasoline Price Fluctuations. National Bureau of Economic Research.

Speth, et.al. 201). Economic and Environmental Benefits of Higher-Octane Gasoline. Environmetal Science Technology, 48(12), 6561-6568. DOI: 10.1021/es405557p

Siddiqui, Rehana. (2004). Energy and Economic Growth in Pakistan. The Pakistan Development Review. 43(2): 175-200.

Sopiana, Yunita. (2006). Analisa permintaan bahan bakar minyak (premium dan solar) sektor transportasi di Indonesia. Pascasarjana IImu Ekonomi FEUI. T 036/06. 